\title{
Use of artificial substrates of different colors for oviposition by the brown stink bug Euschistus heros (Hemiptera, Pentatomidae)
}

\author{
Diones Krinski ${ }^{1}$, Bruna M. Favetti ${ }^{1,2}$, Admar F. Leite-Junior ${ }^{3}$ \& Izabela T. Silva-Gomes ${ }^{4}$
}

\begin{abstract}
${ }^{1}$ Programa de Pós-Graduação em Zoologia, Departamento de Zoologia, Laboratório de Controle Integrado de Insetos, Universidade Federal do Paraná (UFPR), Caixa Postal 19020, 81581-580, Curitiba, PR-Brazil. diones.krinski@ufpr.br

${ }^{2}$ Laboratório de Entomologia do Centro de Estudos, Pesquisa em Desenvolvimento Agro-ambientais (CPEDA), Departamento de Ciências Biológicas, Universidade do Estado de Mato Grosso (UNEMAT), 78300-000, Tangará da Serra, MT-Brazil. favettibruna@yahoo.com.br ${ }^{3}$ Departamento de Agronomia, Universidade do Estado de Mato Grosso (UNEMAT), 78300-000, Tangará da Serra, MT-Brazil. admarlj@hotmail.com

${ }^{4}$ Departamento de Ciências Biológicas, Universidade do Estado de Mato Grosso (UNEMAT), 78300-000, Tangará da Serra, MT-Brazil. iza_tga@hotmail.com
\end{abstract}

\begin{abstract}
Use of artificial substrates of different colors for oviposition by the stink bugs Euschistus heros (Hemiptera, Pentatomidae). Aiming to contribute to a rearing methodology for the brown stink bug, Euschistus heros, in the laboratory, we evaluated oviposition on artificial substrates of different colors. During six days, oviposition was evaluated daily, by counting the total number of eggs, number of clutches, and eggs/clutch. Females laid 12,463 eggs, in 1,677 clutches, resulting in an average of $7.28 \pm 0.44 \mathrm{eggs} / \mathrm{clutch}$. Black, brown, and green felt had the most eggs and clutches. The results demonstrated that many colors are suitable as oviposition substrate for E. heros, providing information for the mass rearing of this insect.
\end{abstract}

KEYWORDS. Biological control; cerrado; insect pest; soybean; Mato Grosso.

Within the complex of insect pests of soybean, the brown stink bug, Euschistus heros (Fabricius, 1798) (Heteroptera, Pentatomidae), is of great interest, as it colonizes the crop since the vegetative phase, causing damage from early stages of pod formation until the ripening of beans (Panizzi et al. 2000a). The attack of this insect reduces oil levels and leaf retention, consequently reducing the quality and commercial value of soybeans (Panizzi \& Slansky-Junior 1985; Schmidt et al. 2003).

Due to the economic importance of $E$. heros, several studies have been conducted to improve rearing techniques of this pest in the laboratory to standardize the availability of eggs in large scale for many biological studies (Parra 2001; Silva \& Panizzi 2009). Therefore, new rearing methodologies along with the need to develop more integrated management practices of stink bug populations have encouraged researchers worldwide to develop mass rearing procedures for several crop pests in the laboratory, mainly aiming at conducting studies to reduce the use of pesticides for the management of stink bugs (Corrêa-Ferreira et al. 2010; Corrêa-Ferreira \& Moscardi 1996; Panizzi \& Corrêa-Ferreira 1997; Corrêa -Ferreira \& Panizzi 1999; Venzon et al. 1999; Knight \& Gurr 2007; Sosa-Gomez et al. 2009; Perez \& Corrêa -Ferreira 2004).

The use of artificial oviposition substrates by several pentatomids for rearing pests and their natural enemies has been proposed by several authors (Shearer \& Jones 1996; Bundy \& McPherson 2000; Panizzi et al. 2000b, 2004; Silva \& Panizzi 2007, 2008), as they are more feasible than natu- ral ones, facilitating the maintenance of stink bug colonies and lowering costs. However, these studies have not examined whether the colors of artificial substrates can interfere with the oviposition of stink bugs, since only white artificial substrates are usually used.

Therefore, the present study examined the oviposition of the brown stink bug, E. heros, on artificial substrates (felt) of different colors, to determine the ideal color for mass rearing this pest insect for studies on its biology, as well as parasitoids for possible biological control.

\section{MATERIAL AND METHODS}

We used specimens of $E$. heros from a colony established in the Laboratory of Entomology of the Center of Agri-Environmental Research, Studies, and Development (Centro de Pesquisas, Estudos e Desenvolvimento Agro-ambientais CPEDA) of the State University of Mato Grosso, Campus of Tangará da Serra (UNEMAT/CUTS).

For the experimental setup, one-day old adults were separated from the main colony and maintained in cages for 9 days, time needed for $E$. heros to reach sexual maturity (Costa et al. 1998). After this period, 10 couples of E. heros were transferred to 8-L plastic containers. In each container, we placed seven pieces of felt $(6 \times 20 \mathrm{~cm})$ always of the same color: white, black, blue, green, red, yellow, or brown. Five replicates were carried out for each color set (container). Adult specimens were sexed according to Borges et al. (2006). The food diet followed Costa et al. (1998) including sunflower 
seeds. The containers were evaluated daily for six days. The experiment was randomized, the results were analyzed with an ANOVA, and the averages were compared with the ScottKnott test, significance set at 5\%, with the software SASM (Canteri et al. 2001).

\section{RESULTS}

Throughout the six days of experiments, we obtained 12,463 eggs in 1,677 clutches, averaging $7.28 \pm 0.44$ eggs per clutch. The colors of felts with the most eggs were black $(2,577)$, brown $(2,380)$, and green $(2,408)$, with no statistical differences. Red $(1,164)$, white $(1,247)$, blue $(1,288)$, and yellow $(1,399)$ were the colors with the fewest eggs. This same pattern was observed for the number of egg clutches.

Regarding the number of eggs/clutch, black (8.6) and brown (8.4) felts had clutches with the most eggs, which were statistically different from green (7.7), red (7.0), and yellow (7.7), followed by white (5.7) and blue felts (5.7) with the fewest eggs per clutch (Table I). The daily average of eggs, clutches and eggs/clutches are presented in Figure 1.

Table I. Average number of eggs, clutches, and eggs/clutch of Euschistus heros obtained from felts of different colors during six days of evaluation without choice chance. Total numbers in parenthesis.

\begin{tabular}{|c|c|c|c|}
\hline \multirow{2}{*}{ Color } & Eggs* & Clutches* & Eggs/clutch* \\
\hline & Mean $\pm \mathrm{SE}^{1}($ total $)$ & Mean \pm SE (total) & Mean \pm SE \\
\hline Black & $429.5 \pm 50.10 \mathrm{a}^{2}(2,577)$ & $48.0 \pm 5.62$ a (299) & $8.6 \pm 0.37 \mathrm{a}$ \\
\hline Brown & $396.6 \pm 52.18$ a $(2,380)$ & $49.8 \pm 4.83$ a (279) & $8.4 \pm 0.27 \mathrm{a}$ \\
\hline Green & $401.3 \pm 22.15$ a $(2,408)$ & $48.0 \pm 2.34 \mathrm{a}(313)$ & $7.7 \pm 0.40 \mathrm{~b}$ \\
\hline Blue & $214.6 \pm 40.05 \mathrm{~b}(1,288)$ & $48.4 \pm 5.19 \mathrm{~b}(218)$ & $5.7 \pm 0.25 \mathrm{c}$ \\
\hline Red & $194.0 \pm 13.25 \mathrm{~b}(1,164)$ & $33.4 \pm 1.91 \mathrm{~b}(166)$ & $7.0 \pm 0.17 \mathrm{~b}$ \\
\hline White & $207.8 \pm 32.99 \mathrm{~b}(1,247)$ & $27.4 \pm 5.25 \mathrm{~b}(219)$ & $5.7 \pm 0.32 \mathrm{c}$ \\
\hline Yellow & $233.1 \pm 21.15 \mathrm{~b}(1,399)$ & $33.8 \pm 2.93 \mathrm{~b}(183)$ & $7.7 \pm 0.47 \mathrm{~b}$ \\
\hline C.V. & 29.66 & 26.13 & 11.29 \\
\hline $\mathrm{F}$ & 8.75 & 5.10 & 12.24 \\
\hline
\end{tabular}

*(p < 0.001); ${ }^{1}$ Standard error (SE); ${ }^{2}$ Means followed by same letter in the column do not differ by Scott Knott test at $5 \%$.

\section{DISCUSSION}

In general, studies on artificial oviposition substrates for stink bugs are scarce. Among earlier experiments, Panizzi et al. (2000b), studying the southern green stink bug Nezara viridula (L.), demonstrated for the first time that a model simulating a natural plant can be used as substrate for oviposition along with an artificial diet. Later, Panizzi et al. (2004) successfully used cheesecloth treated with soybean plant extracts for oviposition of this stink bug.

Silva \& Panizzi (2007) expanded the dataset on the use of artificial substrates by evaluating the oviposition of seven species of pentatomids on cotton balls. Approximately $80 \%$ of clutches of E. heros, Dichelops melacanthus (Dallas), and Thyanta perditor (F.), and $60 \%$ of clutches of Piezodorus guildinii (Westwood) and Chinavia impicticornis (Stål) were laid on cotton balls. However, N. viridula and Edessa
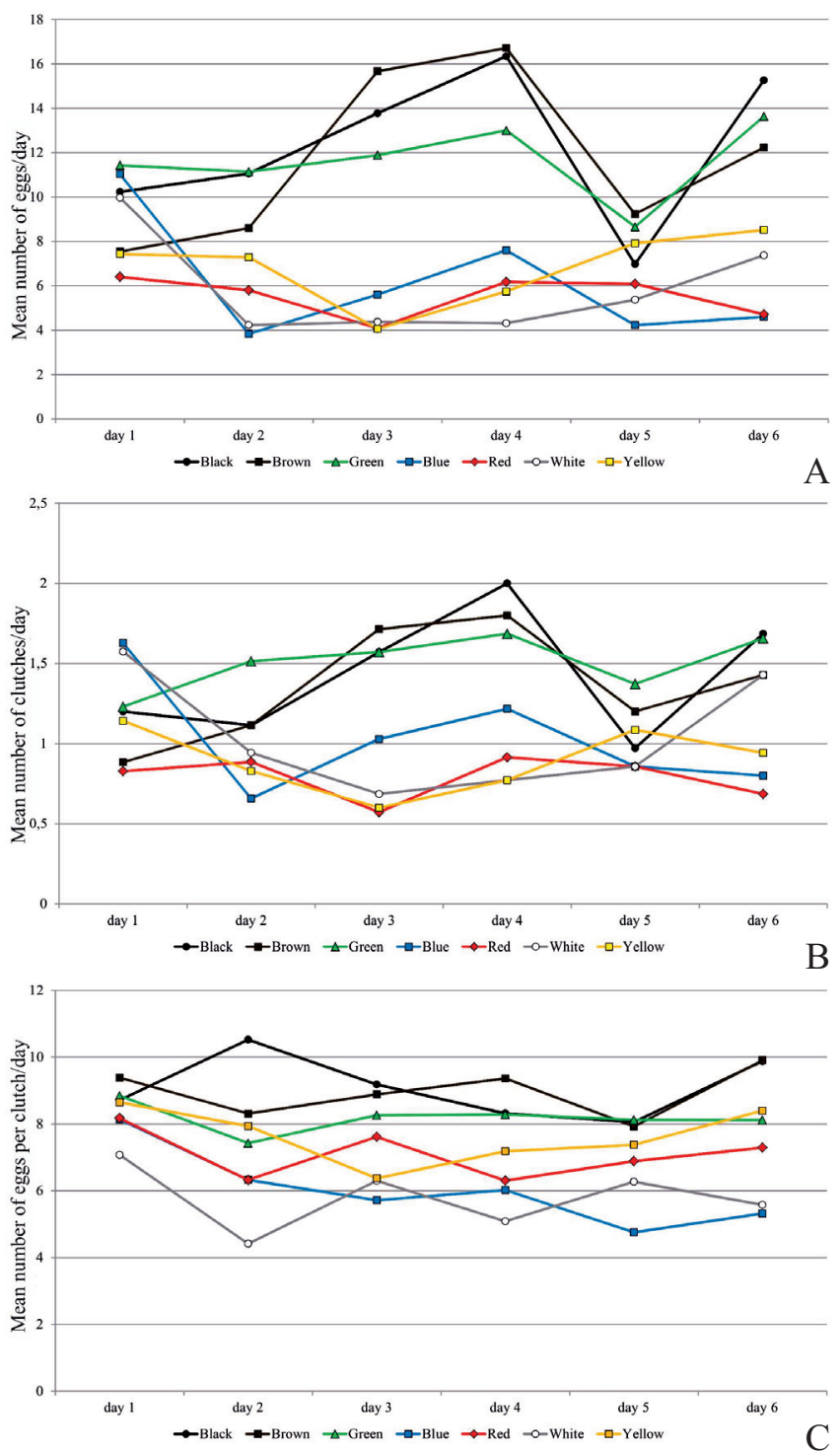

Fig. 1. Daily average number of eggs (A), clutches (B) and eggs/clutch (C) of Euschistus heros on each colored felt.

meditabunda (F.) did not oviposit on this substrate. Silva \& Panizzi (2008) also evaluated the oviposition behavior of the small green stink bug, P. guildinii, on synthetic wool string, cotton string, and cheesecloth, and found that oviposition was highest on the former. In another similar study, Silva \& Panizzi (2009) compared the oviposition of the brown stink bug, E. heros, on artificial substrates (synthetic wool string, cotton string, veil fabric, and cotton balls) and natural substrates (live soybean plants) and found that cotton balls had more eggs compared to live plants. Additionally, the use of cotton balls greatly simplifies routine maintenance in laboratory colonies.

In all these studies, artificial substrates were suitable alternatives to natural ones. However, few studies have examined the relationship between color of oviposition substrate (natural or artificial) and fecundity. Most studies, when examining color, describe its importance in phototactic behav- 
ior (movement in response to light stimuli) (Katsoyannos \& Kouloussis 2001; Drew et al. 2003). McInnis (1989), studying tephritid flies, was one of few that examined the effect of color on fecundity, reporting significantly fewer eggs of $\mathrm{Cer}$ atitis capitata (Wiedemann) in blue substrates, when compared to black and red. Currently, no studies have examined colored artificial substrates on stink bugs.

Silveira-Neto et al. (1976) reported that insects exhibited $100 \%$ of response to wave lengths around $365 \mathrm{~nm}$, which is within the ultraviolet light range. Thus, comparing the wave lengths of colors used in this study (ranging between approximately $400 \mathrm{~nm}$ to $800 \mathrm{mn}$ - light spectrum/visible color) (Souza et al. 2008), of colored felts (black, brown, and green) with the most egg clutches, eggs, and eggs per clutch, green (490$565 \mathrm{~nm}$ ) is the closest to the ultraviolet light range. This suggests that stink bugs oviposit on colored felts closer to this wavelength.

According to Chapman (1998), some insects exhibit a visual pigment with maximum capacity of absorption within the green spectrum range $(490-540 \mathrm{~nm})$, and its range of absorption usually extents below $400 \mathrm{~nm}$, in the ultraviolet range, and above $600 \mathrm{~nm}$, above the green wavelength. However, blue is closer to the ultraviolet wavelength than green, but did not exhibit similar results. Other colors (white, yellow, and red) had a similar pattern to that of blue, suggesting that other factors may influence the oviposition substrate selection. Regarding the results obtained for the red felt, Chapman (1998) points out that for most insects, long wavelengths (red) do not stimulate the eyes, as this color is above the $600 \mathrm{~nm}$ wavelength. Based on this, in our study, red felts are among the colored substrates with the fewest eggs and clutches. This might have occurred due to the sensitivity of insects to light radiations of different wavelengths, often distinct from the human eye (Carvalho 1986).

However, some trends are clear and according to Briscoe \& Chittka (2001), most studied insects have sensitive receptors to the maximum green $(\sim 530 \mathrm{~nm})$. This may explain the larger number of eggs deposited on green felts, since $E$. heros, in its natural habitat, or infesting soybean crops, oviposit on leaves or pods of plants, which are green. Thus, this might be a response associated to the experience of depositing its eggs on green natural substrates (Land \& Chittka 2013). The same may occur with brown felts, similar to soybean stems and mature pods. Gregório et al. (2010) pointed out that oviposition substrate selection in the natural habitat is essential for the survival and success of the offspring. Thus E. heros may associate green and brown felts as natural substrates, since the evolution of color vision in insects cannot be understood without knowledge on the life history of insects, as pointed out by Briscoe \& Chittka (2001).

Therefore, our study demonstrates that the use of artificial oviposition substrates in green, brown, and black were the most appropriate for mass production of E. heros eggs than other tested colors. In addition, the removal of egg clutches was more efficient and free of fuzz, unlike the observed in other studies that used strings and cotton balls as artificial substrates (Silva
\& Panizzi 2007, 2008, 2009). This characteristic is important, especially for egg production for mass rearing of parasitoids, since cotton or wool strings might act as a barrier and interfere negatively with the parasitoid behavior.

\section{ACKNOWLEDGEMENTS}

The authors acknowledge the Universidade do Estado de Mato Grosso, Campus Universitário de Tangará da Serra (UNEMAT/CUTS), for financial support; the researches Mônica Josene Barbosa Pereira and Alessandra Regina Butnariu, and members of the Zoology and Entomology Laboratorys of the Centro de Pesquisas, Estudos e Desenvolvimento Agro-Ambientais (CPEDA) of UNEMAT/ CUTS, for their help; and the physicist Marcos Gonçalves Guimarães Correia Lima of Programa de Pós Graduação em Ensino de Ciências Naturais, Instituto de Física (PPGECN/IF) of Universidade Federal de Mato Grosso (UFMT) for his contributions.

\section{REFERENCES}

Borges, M., Laumann, R.A., Silva, C.C.A., Moraes, M.C.B., Santos, H.M. \& Ribeiro, D.T. 2006. Metodologias de criação e manejo de colônias de percevejos da soja (Hemiptera-Pentatomidae) para estudos de comportamento e ecologia química. Documentos, 182. Brasília, Embrapa Recursos Genéticos e Biotecnologia, 18 p.

Briscoe, A. \& Chittka, L. 2001. The evolution of colour vision in insects. Annual Review of Entomology 46: 471-510.

Bundy, C.S. \& McPherson, R.M. 2000. Morphological examination of stink bug (Heteroptera: Pentatomidae) eggs on cotton and soybeans, with a key to genera. Annals of the Entomological Society of America 93: 616-624.

Canteri, M.G., Althaus, R.A., Virgens-Filho, J.S., Giglioti, E.A. \& Godoy, C.V. 2001. SASM-Agri: Sistema para análise e separação de médias e experimentos agrícolas pelos métodos Scoft-Knott, Tukey e Duncan. Revista Brasileira de Agrocomputação 1: 18-24.

Carvalho, J.P. 1986. Introdução à entomologia agrícola. Lisboa, Fundação Calouste Gulbenkian, 361 p.

Chapman, R.F. 1998. The insects: structure and funcion. Cambridge, Cambridge University Press, 770 p.

Corrêa-Ferreira, B.S. \& Moscardi, F. 1996. Biological control of soybean stink bugs by inoculative releases of Trissolcus basalis. Entomologia Experimentalis et Applicata 79: 1-7.

Corrêa-Ferreira, B.S. \& Panizzi, A.R. 1999. Percevejos da soja e seu manejo. Circular Técnica 24. Londrina, Embrapa Soja, 45 p.

Corrêa-Ferreira, B.S., Alexandre, T.M., Pellizzaro, E.C., Moscardi, F. \& Bueno, A.F. 2010. Práticas de manejo de pragas utilizadas na soja e seu impacto sobre a cultura. Circular Técnica 78. Londrina, Embrapa Soja, 15 p.

Costa, M.L., Borges, M. \& Vilela, E.F. 1998. Biologia reprodutiva de Euschistus heros (F.) (Heteroptera: Pentatomidae). Anais da Sociedade Entomológica do Brasil 27: 559-568.

Drew, R.A. I., Prokopy, R.J. \& Romig, M.C. 2003. Attraction of fruit flies of the genus Bactrocera to colored mimics of host fruit. Entomologia Experimentalis et Applicata 107: 39-45.

Gregório, P.L.F., Sant'ana, J. \& Redaelli, L. R. 2010. Percepção química e visual de Anastrepha fraterculus (Diptera, Tephritidae) em laboratório. Iheringia, Série Zoologia, 100: 128-132.

Katsoyannos, B.I. \& Kouloussis, N.A.2001. Captures of the olive fruit fly Bactrocera oleae on spheres of different colours. Entomologia Experimentalis et Applicata 100: 165-172. 
Knight, K.M.M. \& Gurr, G. M. 2007. Review of Nezara viridula (L.) management strategies and potential for IPM in ûeld crops with emphasis on Australia. Crop Protection 26: 1-10.

Land, M. \& Chittka, L. 2013. Vision, p. 708-737. In: Simpson, S.J. \& Douglas, A.E. (eds.) The Insects: Structure and Function. Cambridge, Cambridge University Press, 954 p.

McInnis, D.O. 1989. Artificial oviposition sphere for Mediterranean fruit flies (Diptera: Tephritidae) in field cages. Journal of Economic Entomology 82: 1382-1385.

Panizzi, A.R. \& Corrêa-Ferreira, B.S. 1997. Dynamics in the insect fauna adaptation to soybean in the tropics. Trends in Entomology 1: 71-88.

Panizzi, A.R. \& Slansky-Junior, F. 1985. Review of phytophagous pentatomids (Hemiptera: Pentatomidae) associated with soybean in Americas. Florida Entomologist 68: 184-214.

Panizzi, A.R., McPherson, J.E., James, D.G., Javahery, M. \& McPherson, R.M. 2000a. Stink bugs (Pentatomidae), p.421-474. In: Schaefer, C.W. \& Panizzi, A.R. (Eds.). Heteroptera of Economic Importance. Boca Raton, CRC Press, $856 \mathrm{p}$.

Panizzi, A.R., Parra, J.R.P., Santos, C.H. \& Carvalho, D.R. 2000b. Rearing the southern green stink bug using an artificial dry diet and an artificial plant. Pesquisa Agropecuária Brasileira 35: 1709-1715.

Panizzi, A.R., Berhow, M. \& Bartelt, R.J. 2004. Artificial substrate bioassay for testing oviposition of southern green stink bug conditioned by soybean plant chemical extracts.. Environmental Entomology 33: 1217-1222.

Parra, J.R.P. 2001. Técnicas de criação de insetos para programa de controle biológico. 6. ed. Piracicaba, FEALQ, 134 p.

Perez, W.A.A. \& Corrêa-Ferreira, B.S. 2004. Methodology of mass multiplication of Telenomus podisi Ash. and Trissolcus basalis (Woll.) (Hymenoptera: Scelionidae) on eggs of Euschistus heros (Fab.) (Hemiptera: Pentatomidae). Neotropical Entomology 33: 457-462.
Schmidt, F.G., Pires, C.S.S., Sujii, E.R., Borges, M., Pantaleão, D.C., Lacerta, A.L.M. \& Azevedo, V.C.R. 2003. Comportamento e captura das fêmeas de Euschistus heros em armadilhas iscadas com feromônio sexual. Comunicado Técnico 93. Brasília, Embrapa Recursos Genéticos e Biotecnologia, 4 p.

Shearer, P.W. \& Jones, V.P. 1996. Suitability of macadamia nut as a host plant of Nezara viridula (Hemiptera: Pentatomidae). Journal of Economic Entomology 89: 996-1003.

Silva, F.A.C. \& Panizzi, A.R. 2007. Cotton balls as an oviposition substrate for laboratory rearing of phytophagous stink bugs (Heteroptera: Pentatomidae). Annals of the Entomological Society of America 100: $745-748$.

Silva, F.A.C. \& Panizzi, A.R. 2008. The adequacy of artificial oviposition substrates for laboratory rearing of Piezodorus guildinii (Westwood) (Heteroptera, Pentatomidae). Revista Brasileira de Entomologia 52: $131-134$.

Silva, F.A.C. \& Panizzi, A.R. 2009. Oviposition of the neotropical brown stink bug Euschistus heros (Heteroptera: Pentatomidae) on artificial and on natural substrates. Florida Entomologist 92: 513-515.

Silveira-Neto, S., Nakano, O., Barbin, D. \& Villa Nova, N.A. 1976. Manual de ecologia dos insetos. Piracicaba, Agronômica Ceres, 419 p.

Sosa-Gómez, D.R., Silva, J.J., Lopes, I.O.N., Corso, I.C., Almeida, A.M.R., Moraes, G.C. \& Baur, M.E. 2009. Susceptibility of Euschistus heros (Heteroptera: Pentatomidae) adults to insecticides used in Brazilian soybeans. Journal of Economic Entomology 102: 1209-1216.

Souza, N.A., Borges, M.N., Ribeiro, C.M. \& Trales, P.B. 2008. Entendimento da mistura de cores facilitado pela articulação entre a Química e a Matemática. Revista Ibero-Americana de Educação 46: 1-14.

Venzon M., Riposati, J.G., Ferreira, J.A.M. \& Viríssimo, J.H. 1999. Controle biológico de percevejos-da-soja no triângulo mineiro. Ciência e Agrotecnologia 23: 70-78. 